\title{
Job Satisfaction in a South African Academic Library in Transition
}

\section{Genevieve Hart}

Department of Library and Information Science, University of the Western Cape, Cape Town, South Africa

\begin{abstract}
Job satisfaction was investigated at a South African university library undergoing change on many fronts. The study included 31 members of staff and the data were gathered via interviews/questionnaires, informed by standard HRM job satisfaction theory. The study found a "love-hate" relationship between respondents and their work. The key positive finding is that $61 \%$ report overall job satisfaction-with the core work of an academic library, providing for the information needs of clients, the source. However, only $51 \%$ claim to be proud to work at their library and $50 \%$ are open to other job offers. Causes for the restlessness include a sense of stagnation, frustration with inadequate resources, and anger at poor remuneration.
\end{abstract}

\section{Introduction}

The article reports on a study of job satisfaction in a South African academic library. The research project had four objectives:

- To investigate a topical issue within human resources management in academic librarianship. Although some of the challenges facing South African academic libraries have been documented, ${ }^{1}$ there has been surprisingly little research in the motivation of their staff.

- To provide information for library leadership. The new director of the library under study has presented a strategic plan and a restructuring proposal which it is hoped will enhance its position within its university. The success of such initiatives depends on the receptivity of library staff to change. ${ }^{2,3}$ Over the years there has been anecdotal evidence of low morale within the library and there has been a spate of resignations in the past two years. The high staff turnover is identified in the Director's strategic plan as "a risk factor for the library's sustainability and service delivery." In an increasingly competitive climate, understanding what keeps people working in academic libraries is essential. ${ }^{4,5}$

- To provide information for librarian educators. The drop in student numbers across all South African library schools in recent years and the aging of the present cohort of professionals are causing concern over the future staffing of libraries. In recruiting students for librarianship, educators need to be in touch with the demands, issues and attractions of the profession.

- To provide experiential learning for final year librarian students. The project was rooted in two modules, Research Methods in LIS and Human Resources Management — both taught in parallel to the same group of students in 2008. It gave students experience of real-life research and they moreover saw how HR theory applies in the world of libraries and information services. The HR 
module is the final module in the management education programme, which prepares graduates to take up professional positions where they will be expected to supervise, manage and lead.

\section{Academic librarianship in transition}

Democracy has brought a new generation of leaders in South African libraries. They are confronted with the same challenges as their peers across the world as well as some specific to South Africa.

There is consensus in the professional literature that the climate for academic libraries since the 1980s has undergone fundamental changes which call for innovative and strategic thinking. ${ }^{6}$ Probably the two major shifts in their management and governance are the stronger emphasis on accountability and systematic quality assessment and the rationalising and merging oflibraries in the wake of the restructuring of tertiary education worldwide. As Brophy ${ }^{7}$ warns, in today's climate of accountability, the onus is on library staff to earn the support of their communities.

Developments in ICT and shifts to electronic publishing have led to a rethinking of the traditional structuring of an academic library. ${ }^{8,9}$ Regional consortia have arisen, providing new opportunities for resource sharing but calling for new mindsets. In response to changes in scholarly communication patterns, many academic libraries are venturing into publishing via open-access research repositories. In tandem with these initiatives, the role of libraries in universities' research programs is being re-examined..$^{10}$

South African university libraries have not been immune from these pressures. In an attempt to transform the apartheid era higher education landscape, the so-called "size and shape" initiative of the Department of Education and the Council for Higher Education has reduced numbers of universities from 32 to 25 through mergers. ${ }^{11}$ In common South African parlance the parent institution of the library reported on in this paper might be labelled an HDI or HBI, a historically disadvantaged or black institution. It takes great pride in its intellectual leadership in the struggle against apartheid in the 1970s and 1980s; and its mission statements today highlight the same commitment to the marginalised. Yet, the university has had to adjust to a new competitive landscape. In post-apartheid South Africa, little allowance is made in funding formulae for historical disparities between historically white and black universities, which are evident, for example, in a comparison of library holdings, ICT facilities and staffing across the region. Nonetheless, despite their relatively thin reserves, the university and its library aspire to rise above labels such as "historically disadvantaged" and "to compete with the best."

Shifts towards learner-centred curricula, as in problem-based and resource-based learning, and to different delivery methods, such as e-learning and short courses, require new approaches to the provision of access to learning and information resources. Traditional library information retrieval systems are being adapted to the information- seeking behaviour of Generation $Y$ students. At the same time, the scarcity of books, libraries and computers in most South African schools means that many first year students lack basic literacy and computer literacy skills, let alone the high-level information literacy skills demanded by higher education. ${ }^{12}$ The library in this study serves a 
university whose student population is mostly black — the implication being that most arrive from disadvantaged schools with virtually no library or computer facilities. ${ }^{13}$

There is comment in the international literature that not enough attention has been paid to the impact of these various changes on library staff. ${ }^{14,15}$ Negotiating these challenges requires flexibility, confidence and positive attitudes. A case study of the impact of change on staff in a university library in the UK in the late 1990s concludes that the negative impact of change can be minimised through "communication and information sharing, staff involvement, training and development, and job design." ${ }^{16}$ These words underlie the investigation described in this article.

\section{Job satisfaction in LIS}

Job satisfaction is generally defined in terms of people's emotional reactions to their jobs. Lim distinguishes between conceptual definitions and operational definitions, in which measures of satisfaction are given, such as a sense of belonging, job autonomy, promotion opportunities, and role identity. ${ }^{17}$

In common with other studies of job satisfaction in LIS, the project is informed by the classic HR theories which are covered in Human Resources Management (HRM) textbooks, specifically Hackman and Oldham's Job Characteristics Model (JCM) of job enrichment and Herzberg's incentives theory. According to the JCM model, designing meaningful jobs, that call for a variety of skills, that have an identity, that offer room for autonomous decision-making and that build in feedback is the key to job satisfaction, motivation, reduced turnover as well as improved performance. Most approaches to workplace motivation and satisfaction agree that employees are motivated by a mix of factors. Some come from outside but equally important are the inner factors related to human needs for growth and learning. ${ }^{18}$ Library leadership has little control of what Herzberg calls "hygiene" factors like remuneration, which are dictated by the parent university. But the agreement in HR theory on the importance of employees' self- motivation provides opportunities. The task of a leader is to provide a motivating climate in which people choose to continuously develop themselves - to the benefit of the organisation. The rise of the notion of a learning organisation in management circles seems particularly appropriate for a library, whose business is the communication of knowledge.

In 1998, Van Reenen's review of job satisfaction studies in LIS found that:

- older staff are more satisfied than younger,

- department heads with more responsibility are happier in their work than the staff under them,

- reference librarians are more satisfied,

- professional staff are more satisfied and

- the biggest cause of satisfaction is working with patrons. ${ }^{19}$

Library Journal's survey of job satisfaction in American libraries ${ }^{20}$ found that $85 \%$ of respondents would choose librarianship again, although there was a strong thread of criticism of library management. 
The research in the impact of change on staff is of particular interest, given the turbulent change that South African libraries have been subjected to in recent years and its pointers to the links between successful change management and staff morale. ${ }^{21}$ The studies of career anchors, such as Willard's survey of long-term Canadian librarians, ${ }^{22}$ are also relevant to the study since, as already mentioned, the library under study has had an increase in resignations in the past few years.

\section{Research project}

The library under study has on paper a staff of 62 , with six of these described as "support." However, there are at least 12 vacant positions - with 13 resignations in the past year (two due to retirement). The analysis provided in the report of the 13 resignations is intriguing. It appears as if only three people have left for more senior positions in other libraries with the others, the report claims, leaving for positions in other neighbouring academic libraries which are at the same level but which apparently offer better remuneration. This claim perhaps cannot be taken at face value. For example, the attraction of better pay might well be deemed the safest comment in an exit interview. The instability in the library's leadership has to be highlighted. The library has had four directors in the past 10 years. The present director was appointed in 2007 and the two longstanding deputy directors have recently retired.

The study's 31 respondents made up 81\% of the 44 existing staff. (At the time of the study there were 14 vacant positions). Disproportionate stratified sampling was used with more intensive sampling taking place in the small departments. The Director and the newly appointed Acting Deputy Director were not included since the population did not include senior management. As mentioned in the introduction, one of the objectives of the study was to provide information for the newly appointed senior management.

\section{Research Questions and Methodology}

The above background and outline of HR theory underlie the questions that the project set out to explore, for example:

- What is the level of job satisfaction among the library staff?

- What are the chief satisfiers and dissatisfiers?

- Do levels of satisfaction vary according to staff grade?

- Is satisfaction or lack of satisfaction a factor in staff plans to stay or leave?

- Given the links between job satisfaction and motivation and performance, what pointers for library leadership can be found to increase motivation and improve performance?

The questionnaire, designed to gather data to explore the dimensions of job satisfaction which were identified in the preceding discussion of job satisfaction theory and research, is provided as an appendix. It includes all types of questions: each type hopefully appropriate to the data desired and the mix allowing for some triangulation of responses across questions. It delves into respondents' perceptions of their job and of their opportunities for growth and development. It asks them about the factors that give them satisfaction or dissatisfaction in their work. It has to be stressed that it reflects people's perceptions. There was no attempt to confirm these by means of job 
analysis and observation, for example. A few questions are aimed at exploring career plans emanating from the concerns over staff turnover described above.

The questionnaires were personally administered as the personal interaction ensured a good response rate and the open-ended questions in particular gave the students some experience of interviewing. The students were prepared in class by means of role plays.

\section{Findings}

The discussion in this section interweaves data gathered across different questions in different sections of the questionnaire. For example, when the responses to the open-ended questions deepen insight into the Likert scale question responses, they are brought into the analysis. Because of the relatively small sample sizes, inferential statistics will not generally be meaningful. Totals and comparative percentages are used to illustrate differences between groups of respondents.

\section{Respondents' Personal Details}

Some respondents in small departments were nervous about anonymity so the findings that follow do not offer departmental breakdowns. Eighteen are women, 13 are men. The median age of respondents is 45.5 years and the average number of years in their present job is 10.5 . Of the 31,13 $(42 \%)$ are in professional posts. Twenty-one have professional qualifications - although in fact only 13 hold professional positions. Given the comment in the job satisfaction literature on differences between professional and non-professional staff, the analysis that follows in the next section at times separates and compares the data gathered from professional staff and so-called nonprofessional. That only four respondents in professional positions have postgraduate degrees and that only one is engaged in postgraduate study is perhaps noteworthy in today's challenging climate.

The fact that several have gained professional degrees while working in the library and are still not in professional positions clearly is a cause of frustration. There are several complaints about "outside" people being appointed to positions ahead of them. For example, on being asked about their dissatisfiers and what might be changed for the better, some reply:

"They do no not acknowledge your years of experience yet you must teach them [new staff from outside]."

"There's no growth-they rather take in new and outside people."

"In interviews do not be more hard on the staff than people from outside."

\section{Staff Development}

The questionnaire includes several questions that explore staff development — via formal education and continuing professional development programmes. Of the 31 respondents, six (five in nonprofessional posts and one in a professional) are presently enrolled for a formal degree or qualification. It is noteworthy perhaps that one of the non-professional staff reports that he/she is enrolled for a Masters degree. It would be interesting to know more about this person's motivation. 


\section{Figure 1}

\section{Staff Development In Past Year $(n=30)$.}

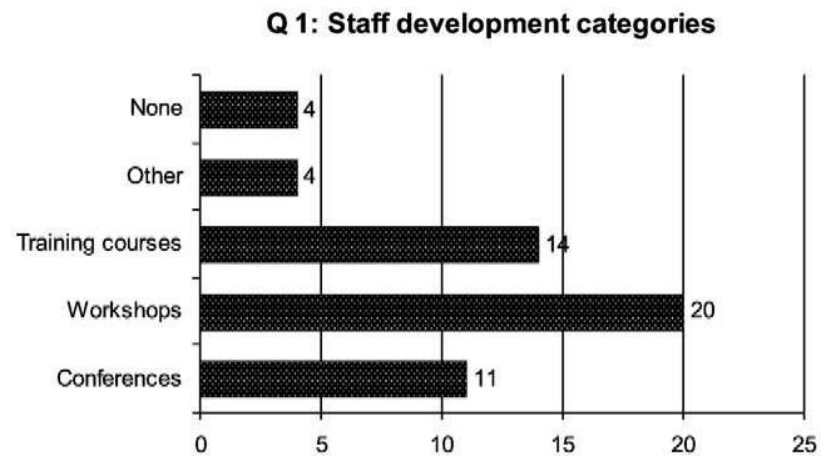

Fig. 1 depicts experience of various categories of professional development in the past year. Twenty six of the 30 who responded reported one or more kinds of continuing professional development. Ten of these 26 attended only one kind of development intervention, nine attended two different kinds and seven attended three different kinds.

The response indicates that staff development is rather sparse. One of the strongest threads in the responses to the open-ended question, What dissatisfies you in your job?, relates to personal development and growth, lending support to this interpretation, for example:

"The first chance I get I would leave bere because you don't grow."

"There's no growth or mobility. They rather take in new people."

"Not being able to attend staff development things — there's no personal development."

"No room for growth — no one has a place for me."

One respondent calls for sideways movement whereby staff - without promotion - might be allowed to transfer to other departments in order to enrich their experience and provide fresh motivation.

\section{Job Identity}

According to the JCM model, job identity is crucial to job meaningfulness. A job should have clarity of purpose within the context of the library mission and other related jobs. All respondents report that they have a job description; however $16(52 \%)$ claim that the description does not match their "real" day-to-day work. This anomaly seems to apply more to non-professional staff than professional as Table 1 shows. 


\begin{tabular}{lcccc}
\hline \multicolumn{4}{c}{$\begin{array}{c}\text { Table 1 } \\
\text { Gap Between Job Descriptions And Day-To-Day } \\
\text { Experience }(\boldsymbol{n}=\mathbf{3 1})\end{array}$} \\
\hline $\begin{array}{c}\text { Does job } \\
\text { description } \\
\text { match }\end{array}$ & & & & \\
experience? & Non-professional & Professional & Blank & Total \\
\hline Yes & 7 & 8 & & 15 \\
No & 10 & 5 & 1 & 16 \\
Grand Total & 17 & 13 & 1 & 31 \\
\hline
\end{tabular}

The anomaly has to be treated with caution. Apart from clarity of purpose, another characteristic of meaningful work is that it provides for people's need for growth and expanded responsibilities. It could be that the existing job descriptions relate to the basic job requirements and do not include opportunities for enrichment that have been added on. However, another counter argument could be that enlarging a job with more senior responsibilities without recognition or reward can in fact be de-motivating. This second possibility is supported by several replies to later open-ended questions, which reveal discontent that people are not acknowledged or rewarded for what they do.

A related factor is the pressure caused by the current shortage of staff. There might well be no room for enriching people's work when departments are operating with a skeleton staff. The impact is as much on quality of service as on individual staff development as evidenced in the regret expressed by a recently appointed head of department who says:

"We're so short staffed - I would love to do more but cannot."

\section{Attitudes to the Job: Satisfaction, Pride and Workplace Commitment}

This section begins with the question which asks respondents to rate their overall job satisfaction on a scale of strongly dissatisfied, dissatisfied, neutral, satisfied and strongly satisfied. Fig. 2 depicts the responses. Nineteen (61\%) report satisfaction or strong satisfaction (1); 12 are neutral, dissatisfied or strongly dissatisfied (2). There appears to be a higher level of satisfaction among professional staff with $76 \%$ of this group reporting overall satisfaction.

Figure 2

Overall Job Satisfaction $(n=30)$

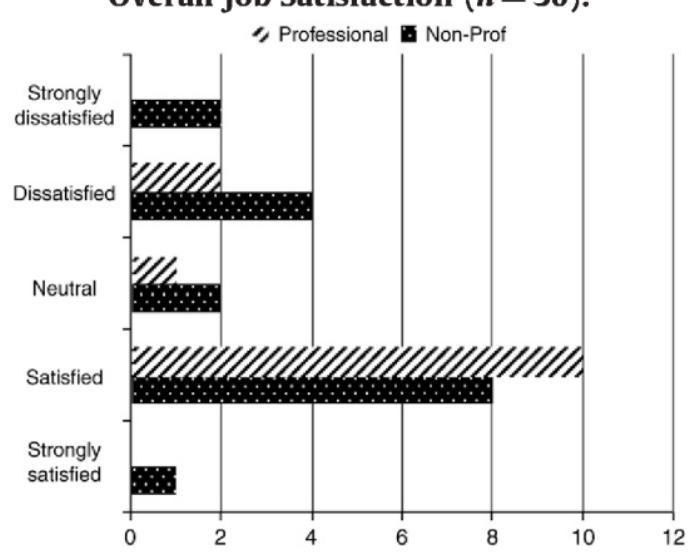


This broad response can be more closely analysed by a comparison with the answers to the later questions exploring respondents' organisational commitment and sense of belonging.

Fig. 3 shows that only $16(51 \%)$ report that they are proud to say they work at the library indicating a lack of the sense of belonging identified as significant to job satisfaction (Lim, 2008).

Figure 3

“I Am Proud To Say I Work At Library X" $(n=30)$.

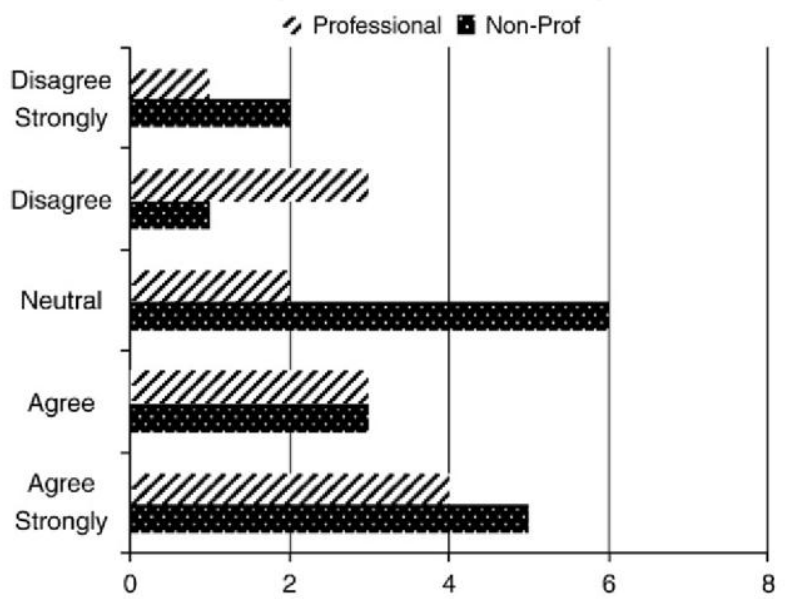

Table 2 shows that about the same number, 15, report that they are at present looking for another job.

\begin{tabular}{lcccc}
\hline \multicolumn{5}{c}{ Table 2 } \\
Are You Looking For A Job Outside Your Library At The \\
Moment? $(\boldsymbol{n = 3 1 )}$
\end{tabular}

Fig. 4 summarises the answers to Question 11, which asks if respondents would accept a job offer outside their library with the same pay and without loss of benefits. The aim was to isolate remuneration issues. Fourteen (48\%) say Yes with another five unwilling to answer. 


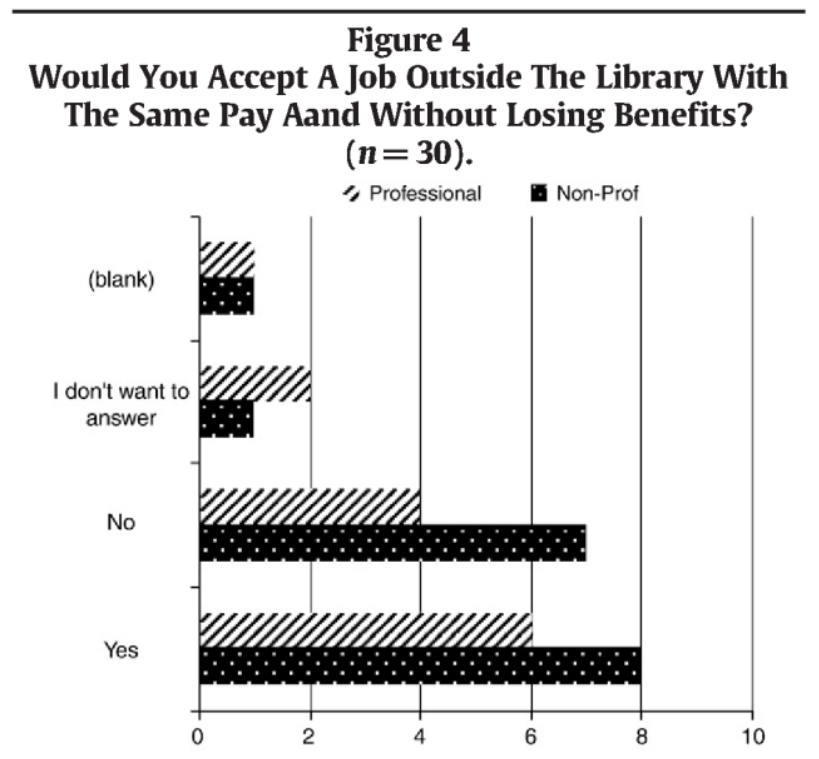

Table 3 summarises the answers to the question: Where do you see yourself in three years time?

Twelve aspire to promotion within their library - 10 of the 12 being at present in non-professional positions. But 12 respondents (39\%) see themselves as having left the library. Reasons for leaving are evenly divided between a perceived lack of promotion prospects and a sense of stagnation in their present jobs. Some of the responses to a later open-ended question support this interpretation, for example:

"I do the same things every day."

"No advancement....

"I' $m$ tired and bored."

\begin{tabular}{|c|c|c|c|c|}
\hline \multicolumn{5}{|c|}{$\begin{array}{c}\text { Table } 3 \\
\text { Where Do You See Yourself In } 3 \text { Years Time? }(n=31)\end{array}$} \\
\hline $\begin{array}{l}\text { Where do you } \\
\text { see yourself in } \\
3 \text { years time? }\end{array}$ & $\begin{array}{c}\text { Non- } \\
\text { professional }\end{array}$ & Professional & Blank & Total \\
\hline In my same job & & 2 & & 2 \\
\hline $\begin{array}{l}\text { In a more senior } \\
\text { job in your } \\
\text { university library }\end{array}$ & 10 & 2 & & 12 \\
\hline $\begin{array}{l}\text { Working at a more } \\
\text { senior level in } \\
\text { another library }\end{array}$ & 3 & 1 & 1 & 5 \\
\hline Working outside LIS & 4 & 3 & & 7 \\
\hline I never think about it & & 3 & & 3 \\
\hline Other & & 2 & & 2 \\
\hline Grand total & 17 & 13 & 1 & 31 \\
\hline
\end{tabular}

Cross tabulating responses to the above questions throws further light on the issues.

Nonparametric rank correlation between levels of agreement with overall job satisfaction and pride in working at the library is significantly positive (Spearman $r=0.484, p=0.0058, n=31$ ). 
Table 4 compares those currently satisfied with their jobs and those not satisfied, in terms of their intentions to leave the library. It then does the same for those who claim to be proud to work at the library and those not proud to do so. It is clear that those who are currently dissatisfied with their job or are not proud to work at the library plan to leave, whereas the majority of those who are satisfied and/or proud plan to stay.

In Table 4 the different percentages for the satisfied and dissatisfied groups are also compared for statistical significance using Yates corrected Chi-square test, which caters conservatively for small sample sizes. The level of dissatisfaction is associated significantly with intention to look elsewhere, even without better pay or benefits. Level of pride is also significantly associated with willingness to move to another job with no increase in benefits. Table 4 underlines the importance for library leadership of satisfied staff. Dissatisfied people will leave.

Table 4

Workplace Commitment Versus Satisfaction and Pride in Current Job

\begin{tabular}{|c|c|c|c|}
\hline Overall job satisfaction & $\begin{array}{l}\text { Satisfied or } \\
\text { Very Satisfied }\end{array}$ & $\begin{array}{c}\text { Dissatisfied or } \\
\text { Very Dissatisfied }\end{array}$ & $\begin{array}{l}\text { Yates Corrected } \\
\text { Chi-Square }\end{array}$ \\
\hline \multicolumn{4}{|l|}{ Percentage of those in each group who: } \\
\hline Are looking for a job outside $(n=27)$ & $44 \%$ & $100 \%$ & $4.37 ; p=0.037$ \\
\hline Would accept a job with same pay and benefits $(n=26)$ & $38 \%$ & $100 \%$ & $6.95 ; p=0.008$ \\
\hline "I feel proud to say I work at Library X" & $\begin{array}{c}\text { Agree or } \\
\text { Strongly Agree }\end{array}$ & $\begin{array}{c}\text { Disagree or } \\
\text { Strongly Disagree }\end{array}$ & $\begin{array}{l}\text { Yates Corrected } \\
\text { Chi-Square }\end{array}$ \\
\hline \multicolumn{4}{|l|}{ Percentage of those in each group who: } \\
\hline Are looking for a job outside $(n=27)$ & $43 \%$ & $83 \%$ & $1.39 ; p=0.239$ \\
\hline Would accept a job with same pay and benefits $(n=26)$ & $36 \%$ & $100 \%$ & $4.66 ; p=0.031$ \\
\hline
\end{tabular}

Those leaving may go to another library or leave the profession. Of the seven respondents in Table 3 who see themselves working outside LIS in three years' time, only one was proud to work at the library, two were neutral and four not proud to be working at the library. Of these same seven, however, three were currently satisfied and three not satisfied overall with their jobs.

\section{Satisfiers and Dissatisfiers}

Responses to Question 4's 12 Likert scale statements provide the opportunity for a more nuanced analysis of respondents' job satisfaction. The statements probe perceptions and experiences on a variety of job attributes that HR theory deems significant to job satisfaction, for example,

- remuneration,

- recognition from management,

- regular feedback and good communication flow,

- faith in the leadership and trust that it cares about staff,

- staff morale and team spirit,

- opportunities for challenge, accomplishment, growth and autonomous decision-making and task variety. 
Fig. 5 gives the statements and arranges the responses in order of least agreement to most. Thus its first entry shows that only $4(13 \%)$ believe their remuneration is fair and at the other end $24(77 \%)$ agree that their jobs have a variety of tasks. The most significant finding from the data in Fig. 5 is the indication of low staff morale — with $77 \%$ reporting that morale is low and $55 \%$ negative about team spirit. The relatively high number (64\%) who feel that their job gives a sense of personal accomplishment suggests that the low morale might emanate from a sense of not being recognised or valued rather than the work itself. Thus, $54 \%$ (15) feel that the value of their work is not recognised by management; only $35 \%$ (11) feel that management cares about staff; and only $22 \%$ (7) claim to get feedback on how they do their work. Of concern is the low number of respondents $(32 \%)$ who believe that library management is in touch with internal issues whatever they might be.

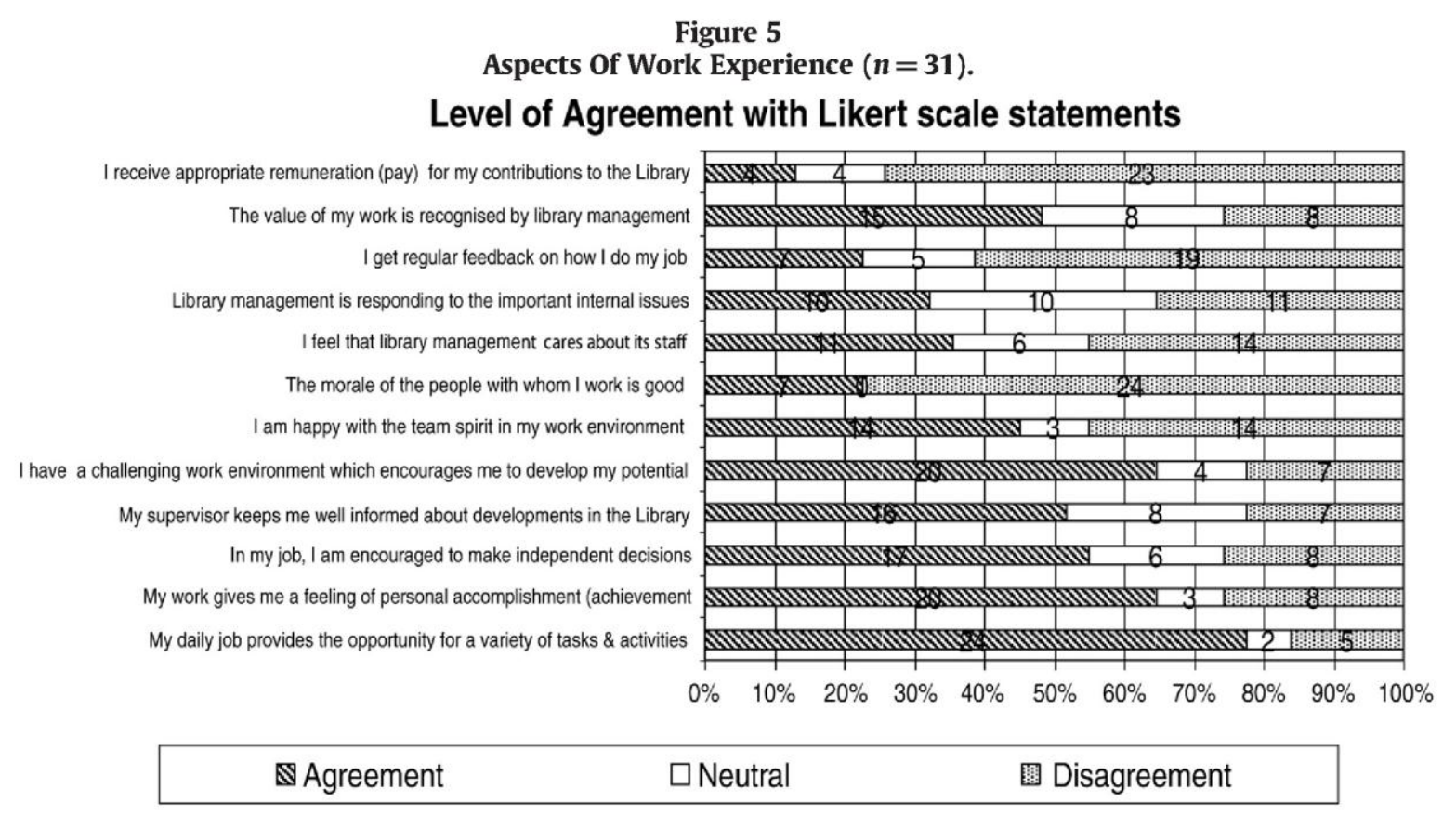

Responses to the open-ended Questions 8 and 9, which simply ask respondents to describe the aspects of their work that satisfy them and that dissatisfy, lend some support to this analysis. The responses were analysed and categorised into units of meaning, some of them interlinked. Table 5 depicts the satisfiers in units of meaning in order of most common to least - with selected illustrative responses. In line with Fig. 5's analysis of the Likert scale statements, the most frequent comments relate to attributes of the work itself and the sense of accomplishment it brings. 


\begin{tabular}{|c|c|}
\hline \multicolumn{2}{|r|}{ What Satisfies You In Your Work? $(n=31)$} \\
\hline Units of Meaning & Example of Responses \\
\hline \multirow[t]{2}{*}{ Positive feedback from students } & $\begin{array}{l}\text { "when students come to thank you when they get good marks and you have helped them with the info } \\
\text { needed" }\end{array}$ \\
\hline & "recognition of work done by academic departments" \\
\hline \multirow{2}{*}{$\begin{array}{l}\text { Serving/helping customers to meet their } \\
\text { information needs }\end{array}$} & "to be able to assist users" \\
\hline & "helping people find the right materials" \\
\hline \multirow[t]{3}{*}{ Customer/people relations } & "I'm a people's person who loves helping people" \\
\hline & "interactions with students and faculty" \\
\hline & "1-on-1 relationship with users - you get immediate feedback" \\
\hline \multirow[t]{4}{*}{ Personal accomplishment } & "completion of a task that I have set to do." \\
\hline & "the number of records I catalogue per day" \\
\hline & "to be able to master different challenges" \\
\hline & "when accomplishing a specific goal" \\
\hline \multirow[t]{3}{*}{ Personal growth } & "it's challenging" \\
\hline & "being able to make my own independent decisions" \\
\hline & $\begin{array}{l}\text { "changes in work with students - e.g., e-learning intrigues me. How does it change the way students } \\
\text { learn and how we relate to them? Where do we fit in?" }\end{array}$ \\
\hline Variety of tasks & "I like an active work environment" \\
\hline \multirow[t]{2}{*}{ Collegiality } & "here is understanding in our department - everybody has respect for each other's needs" \\
\hline & "communication between staff members is healthy" \\
\hline \multirow[t]{2}{*}{ User education } & $\begin{array}{l}\text { "I am able to get resources but also show them how to become independent users by assisting user } \\
\text { education" }\end{array}$ \\
\hline & "when you train students and you see that they start to understand how to find information" \\
\hline \multirow[t]{2}{*}{ Professionalism (e.g. networking) } & "fulfilling my duties as a librarian" \\
\hline & "I have liked the changes in the information world - and in how we access information" \\
\hline \multirow[t]{2}{*}{ Information retrieval } & "I enjoy doing research for academics" \\
\hline & "putting theory into practice" \\
\hline Electronic information resources & "we are electronically on a par with other universities" \\
\hline \multirow[t]{2}{*}{ Physical environment } & "I like the physical set-up" \\
\hline & "I like my working environment" \\
\hline Academic environment & "I like the academic environment" \\
\hline
\end{tabular}

The chief categories of job satisfiers relate to the interaction with students that work in an academic library brings. "Working with people," as in providing information services for students and academics, is the second most mentioned satisfier. Related to this theme is the satisfaction in educating students to become information literate and independent library users.

The next group of data categories refers to opportunities for personal accomplishment and the ongoing learning that work in the library provides. It seems that these opportunities are related to inner drive rather than to organisational climate. Thus, one respondent, while expressing discomfort with the "viciousness" in the environment, reports that she has extraordinary room to "do her own thing" saying, "I've done things here that I would never have done in another university." This is what keeps her in her job. Some describe their satisfaction in attaining work goals they set themselves. Three people refer to their enjoyment of the variety in their work. Another respondent reports that she is challenged and "intrigued" by recent shifts towards e-learning, which have led her to wonder how the library's role in learning will change. 
Of interest to librarian educators are the references to the enjoyment of using professional education, with one reporting that she likes putting theory into practice and another just saying that "performing her duties as a librarian" gives her satisfaction. In line with the references to the satisfaction in serving users that were mentioned earlier, there are a few specific positive references to the joys of searching for information for a high-level researcher. Two comment on their satisfaction from new ICT and electronic information resources, which have allowed them to provide better services after years of lagging behind other advantaged institutions.

The open-ended Question 9 asks respondents to list the things that cause them dissatisfaction in their jobs. Table 6 depicts the analysis of responses to Question 9 in 14 units of meaning from most frequent to least, with illustrative quotations from the interviews. Dissatisfaction with remuneration is the strongest thread. One respondent claims that their salaries are lower than any other South African university library. Discontent comes from perceptions of unfairness within grades as much as the low rates of pay. Another strong thread is the frustration of working with too few resources — staff, equipment and materials budgets.

Comments on conflict among the staff confirm the issue of staff morale referred to earlier. One respondent's comment is so strong that it has to be highlighted:

"There is a viciousness here that can upset you totally. This place — it's a mess.

I ask sometimes: 'Are these people buman?' After all they have children and

families. It's a tough situation — sometimes it just gets to you."

It is clear that satisfiers and dissatisfiers are mirror images of each other. Thus, the universal need for personal growth and development is evident in its prominence in both tables - in one, opportunity for growth being a cause for satisfaction and, in the other, the lack of it a cause of discontent. The several mentions of the frustration caused by small budgets and resulting inadequacy in collections and user services must be seen with the positive comments on the benefits of the relatively new access to electronic and online resources. Respondents enjoy working with students; but their lack of information skills, emanating from their inadequate schooling, can hinder interaction.

\section{Conclusions}

All in all, the study reveals a complex "love-hate" relationship among its participants with their jobs. They believe in and like the work; but at the same time are full of complaints. These complaints clearly have to be listened to if the university is to rise to the challenges of change.

Overall, the findings of the study reflect general HR theory and echo previous research in academic libraries in other parts of the world..$^{23,24}$ As Berry's title puts it, "The work is great but there are genuine problems." 25 The findings hold some clear messages for leadership, inside and outside the library, and for the staff as a whole. The fundamental finding is that the core work of an academic library - serving the information needs of academics and students - is the major source of job satisfaction. The everyday challenge of new learning is a strong motivator. This is especially welcome news to a librarian educator. 


\begin{tabular}{|c|c|}
\hline \multicolumn{2}{|r|}{$\begin{array}{c}\text { Table } 6 \\
\text { What Causes You Dissatisfaction? }(n=31)\end{array}$} \\
\hline Units of Meaning & Example of Responses \\
\hline \multirow[t]{2}{*}{ Remuneration } & $\begin{array}{l}\text { "Because of long years of service, loyalty, we are not on par with rest of the market outside } \\
\text { and those new coming in get to negotiate a new salary for them and we stay behind. Many } \\
\text { left in our section for better salaries and we were left with their workload and no salary } \\
\text { improvements for years." }\end{array}$ \\
\hline & $\begin{array}{l}\text { "All people are not treated the same/people that are here for less years than you get the } \\
\text { same salary." }\end{array}$ \\
\hline $\begin{array}{l}\text { Staff vacancies and shortages leading to } \\
\text { unfair pressures on remaining staff }\end{array}$ & $\begin{array}{l}\text { "So short-staffed - I would love to do so much more but cannot. When my assistant goes } \\
\text { to class I have to take her place." }\end{array}$ \\
\hline \multirow[t]{3}{*}{ Inadequate opportunity for development } & "Being unable to improve career expectations of staff." \\
\hline & "Not being able to attend staff development based on personal development as motivation." \\
\hline & "The first chance I get I would leave her because you don't grow." \\
\hline \multirow[t]{2}{*}{$\begin{array}{l}\text { Lack of promotion prospects - } \\
\quad \text { outsiders get posts }\end{array}$} & $\begin{array}{l}\text { "People with qualifications should be taken into account - and those without } \\
\text { qualifications should not be their seniors." }\end{array}$ \\
\hline & "They do no not acknowledge your years of experience yet you must teach them (new staff)." \\
\hline \multirow[t]{2}{*}{ Conflict among staff } & $\begin{array}{l}\text { "There is a viciousness here that can upset you totally. This place - it's a mess. I ask } \\
\text { sometimes: 'Are these people human?' After all they have children and families. It's a } \\
\text { tough situation sometimes it just gets to you." }\end{array}$ \\
\hline & "Backstabbing: they cannot communicate with colleagues they have to run to management." \\
\hline \multirow[t]{5}{*}{ Staff shortcomings - laziness, etc. } & "Staff not pulling their weight." \\
\hline & "Latecoming of staff." \\
\hline & "Dishonesty." \\
\hline & "Incapable section manager (lack of people skills)." \\
\hline & "I have to work with colleagues that just don't care what the roles are to deliver a service." \\
\hline \multirow[t]{3}{*}{ Poor communication from leadership } & "Our management meetings - go on for hours. It's ridiculous." \\
\hline & "Lack of accountability - no response to query/request from line managers." \\
\hline & $\begin{array}{l}\text { "Communication - for example, I get no response to my emails in which I make } \\
\text { suggestions, etc." }\end{array}$ \\
\hline \multirow[t]{2}{*}{ Poor leadership } & $\begin{array}{l}\text { "Poor leadership: there's contradiction between what is said in meetings and the reality. } \\
\text { For example client centred services is preached but I'm not allowed to build my own } \\
\text { client relationships." }\end{array}$ \\
\hline & "Independent thinking and action is frowned on." \\
\hline Inadequate resources & $\begin{array}{l}\text { "I do my own selecting but my budget is too small. It has not changed for } 4 \text { years. I could } \\
\text { not manage without CALICO." }\end{array}$ \\
\hline \multirow{4}{*}{$\begin{array}{l}\text { Leadership's lack of appreciation for } \\
\text { one's work }\end{array}$} & "Management must recognise the role of staff and show appreciation." \\
\hline & "People not acknowledged for what they are doing." \\
\hline & "Impact of job not acknowledged in terms of salary and recognition." \\
\hline & "I get no support from middle management." \\
\hline Working conditions and lack of flexibility & $\begin{array}{l}\text { "Getting class period from the department to conduct library skills training and my line } \\
\text { manager does not approve that time slot to be used back because I will not get the time } \\
\text { used back. I continue to offer training when possible though I know I will not get my } \\
\text { time off." }\end{array}$ \\
\hline \multirow[t]{4}{*}{ Physical environment } & $\begin{array}{l}\text { "Working conditions - space is too small, one does not own one's own office. I have no } \\
\text { privacy at work due to congestion." }\end{array}$ \\
\hline & "Lack of proper equipment." \\
\hline & “Computer system stinks." \\
\hline & "Air conditioner is pathetic." \\
\hline \multirow[t]{2}{*}{ Students' attributes } & "Lack of library skills." \\
\hline & “Unruly behaviour." \\
\hline
\end{tabular}

However, as Bell ${ }^{26}$ and Topper $^{27}$ warn, having identified a passion for academic librarianship, the challenge for leadership is to sustain it. The respondents, in common with those in Willard's study of Canadian academic librarians, ${ }^{28}$ enjoy their academic library work but reveal little organisational commitment - as evidenced in the recent high staff turnover and the high number who claim to be open to new jobs outside the institution. 
The major pointers for concern include the following:

- The virtually unanimous discontent over remuneration - caused by anomalies within the existing pay scales and perceptions that other academic libraries offer better salaries. The post-apartheid job market has brought new mobility and perhaps the emotional appeal of the university's anti-apartheid struggle credentials can no longer outweigh its low salaries.

- The rather weak sense of belonging as evidenced in the low number who report that they are proud to say they work at their library and the openness to other jobs even if they pay no better.

- The perceived lack of recognition and acknowledgment by leadership — in and outside the library. There is a perception that their university undervalues its library staff.

- The pressures of working with too few resources - especially human resources. These pressures have to be seen against the backdrop of the pressures for change within academic librarian- ship that were described in the introduction.

- The anger over "outsiders" being appointed. Library leadership clearly needs to communicate better the value of fresh ideas and leadership.

- A suggestion of lack of trust in the library leadership. Given the newness of the present director, this is probably inherited from the past instability in leadership. There is a general sense that the leadership is out of touch with the "issues" and that better communication is needed. The study echoes the dissatisfaction with leadership reported in international research. ${ }^{29}$

One respondent's claim that "if the problems in the library can be addressed, staff's attitudes would change" point to the need for follow-up work by library leadership. The study provides evidence of tension in the work climate. As mentioned in an earlier section, existing research has linked conflict among academic library staff to the pressures of the rapidly changing environment. An example, in the late 1990s, is the eLib IMPEL2 study of 23 university libraries in the United Kingdom, which found widespread evidence of conflict among staff, arising from political and educational change, rapid introduction of technology and scarce financial resources. ${ }^{30}$ All of these "issues" apply to the library under study.

\section{Students' reflections}

One of the objectives of the study was to provide experiential learning for final year librarian students. The desired outcomes were that students deepen their insight into HRM issues and learn research skills. Their reflections on the challenges indicate that, on the whole, these outcomes were achieved, for example:

"Overall it was challenging at all levels because we dealt with people and emotions and we had to interpret the underlying meaning of some statements. It was a great experience."

"The data interpretation was challenging because it had to be 100\% accurate more especially in the recording of the information." 
"The most challenging aspect for me was putting the data together and making conclusions on the findings.... Conducting the interviews at first was also a bit challenging as one was a bit nervous.. Overall the project was both interesting and challenging. It tested many skills and most certainly equipped us with knowledge that we will find useful in our future jobs as managers."

\section{Recommendations}

In common with academic libraries everywhere, the library in this study has undergone a period of turbulent change. According to its new director it now faces another period of re-structuring. If the plans are to succeed, attention has to be paid to the people in the library. If the prevailing rather negative climate is to be improved, there needs to be honest debate on expectations of leadership. Staff members will need to confront their own shared responsibility to lead in their own sphere.

The new leadership will have to tackle with courage the weak institutional commitment. In showing how satisfaction is linked to openness to other job offers, the study highlights the significance of job satisfaction for the future of the library.

The respondents themselves provide insightful recommendations when asked to list some changes that might improve their levels of job satisfaction. The following list represents the chief suggestions:

- fill vacant posts quickly,

- restructure library staffing and pay scales,

- evaluate staff more meaningfully — for example benchmark performance delivery standards,

- acknowledge and reward staff for commitment and good performance,

- allow more autonomy and room for initiative,

- rotate staff,

- get more support and interest from the academic community.

The evident frustration over lack of opportunity perhaps might be alleviated if the promised restructuring of the library were to create some entry level professional posts. Recent job advertisements for quite junior positions insist on several years of "relevant" experience, which excludes those staff still in non-professional posts who have spent years upgrading their qualifications. A mentoring programme might enrich the working life of library staff, whose median age is 45.5 years, and might build confidence in the future. Exploration of the concept of the library as a learning organisation, mentioned earlier, could underlie this project.

The key positive finding that the work in the library itself provides a sense of personal accomplishment and is a major source of satisfaction shows the way forward. Respondents across the board, moreover, highlight their satisfaction in working with students from disadvantaged backgrounds. If the library is to contribute to the transformation of the educational and research programmes of its parent university in the context of post-apartheid higher education, its leadership and staff must build on this evidence of shared vision. 


\section{Appendix A. Supplementary data}

Supplementary data associated with this article can be found, in the online version, at doi:10.1016/j.acalib.2009.11.006.

\section{Notes and References}

1.G. Thomas, "Academic libraries and the second decade of democracy: critical issues and challenges," in: T. Bothma, P. Underwood, P. Ngulube (Eds.), "Libraries for the future: progress and development of South African libraries," LIASA, Pretoria, 2007, pp. 71-88.

2.C. Edwards \& G. Walton, "Change and conflict in the academic library," Library Management 21 (2000): 35-41.

3. FarleyJ. Broady-Preston \& T. Hayward, "Academic libraries, people and change: a case study of the 1990s," Library Management 19 (1998): 238-251.

4.D.M. Willard, "Why do we stay? Survey of long-term academic librarians in Canada," portal: Libraries and the Academy 3 (2003): 99-111.

5.E.F. Topper, "Job satisfaction in libraries: love it or leave it," New library world 109 (2008): 287-290.

6. E.J. Wood, R. Miller, \& A. Knapp, "Beyond survival: managing academic libraries in transition,", Libraries Unlimited, Westport, Conn, 2007.

7.P. Brophy, "The library in the twenty-first century: new services for the information age,", Library Association, London, 2007.

8. T. Farley, J. Broady-Preston, and T. Hayward, ibid.

9. C. Edwards \& G. Walton, "Change and conflict in the academic library," Library Management 21 (2000): 35-41.

10. J. Webb, P. Gannon-Leary, \& M. Bent, "Providing effective library services for research,", Facet, London, 2007.

11. G. Thomas, ibid.

12. K. de Jager and M. Nassimbeni, "Can they and do they? Exploring information literacy tuition in South African tertiary institutions," Paper presented at LIASA Annual Conference, Port Elizabeth, September 2002. Available: http://home.imaginet.co.za/liasa/ 2002papers.htm (November 4, 2008).

13. G. Hart, "Information literacy: the missing link in South Africa's educational transformation?," in: H. Asamoh-Hassan (Ed.), "Sub- Saharan Africa colloquium on information literacy and lifelong learning," UNECA, Addis Ababa, 2007, pp. 116-126.

14. C. Edwards and G. Walton, ibid.

15. T. Farley, J. Broady-Preston and T. Hayward, ibid.

16. T. Farley, J. Broady-Preston and T. Hayward, ibid, p. 249.

17. S. Lim, "Job satisfaction of information technology workers in academic libraries," Library and Information Science 30 (2008): 115-121.

18. J. Adair, "Leadership and motivation: the fifty-fifty rule and eight key principles of motivating others,", Kogan Page, London, 2007.

19. J. Van Reenen, "Librarians at work: are we as satisfied as other workers?," Information Outlook 2 23-26 (1998): 28. 
20. J.N. Berry, "LJ series — job satisfaction: great work, genuine problems," Library journal 132 (2007): 26-29.

21. C. Edwards and G. Walton, ibid.

22. D.M. Willard, "Why do we stay? Survey of long-term academic librarians in Canada," portal: Libraries and the academy 3 (2003): 99-111.

23. D.M. Willard, ibid.

24. A. Koustelios, A. Togia, \& N. Tsigilis, "Job satisfaction among Greek academic librarians," Library and information science research 26 (2004): 373-383.

25. J.N. Berry, ibid.

26. S.J. Bell, "A passion for academic librarianship: find it, keep it, sustain it - a reflective enquiry," portal: Libraries and the Academy 3 (2003): 633-642.

27. E.F. Topper, "Job satisfaction in libraries: love it or leave it," New library world 109 (2008): 287-290. 28. D.M. Willard, ibid.

29. J.N. Berry, ibid.

30. C. Edwards and G. Walton, ibid, p. 40. 